doi: https://doi.org/10.15407/econlaw.2018.02.111

UDC 353.8

O.Yu. KUDRINA, Dr. of Economic Sciences, professor, Head of the Department of Economics and Business Sumy State Pedagogical University named after A.S. Makarenko, Sumy, Ukraine (iD) orcid.org/0000-0002-7364-1998

O.K. DATSENKO, postgraduate student

Sumy State Pedagogical University named after A.S. Makarenko, Sumy, Ukraine

(iD) orcid.org/0000-0002-0369-2132

\title{
SOCIO-ECONOMIC SECURITY AS A FACTOR FOR RAISING THE LEVEL OF COMPETITIVENESS OF REGION
}

Keywords: sustainable development of the region, competitiveness of the region, the economic security of the region, socio-economic security of the region.

\footnotetext{
(C) O.Yu. KUDRINA,

O.K. DATSENKO, 2018
}

The article analyzes the concept of social and economic security in the context of state development of the regions. Issues of the impact of socio-economic security on the competitiveness of the region. The influence of competition on the development of regions is investigated. The main factors and objective of socio-economic security of the region are considered. The basic properties of the concept of a region's competitiveness are analyzed.

Statement of a scientific problem. Destabilizing factors and uneven development of the region with low living standards creates an environment for the emergence of tension in society. This, in turn, creates threats that affect the territorial integrity of the country, impedes market transformation and reduces the effectiveness of the introduction of new reforms in the state. Therefore, the regional policy of the state should be aimed at creating conditions for improving the competitiveness of the regions as a basis for their dynamic development and elimination of significant interregional imbalances.

Analysis of publications. Competitiveness of the region and its evaluation are considered in the works of such foreign and domestic scientists as M. Porter, R. Fatkhudinov, I. Ansoff, A. Voronkov, P. Drucker, and others. While the socio-economic security of the regions is considered in the work N. Kolenda, O. Reznikov, V. Antoshkin, G. Kozachenko, V. Ponomareva, O. Lyashenko, O. Simonova, S. Smirnov.

The purpose of the article is to develop the theoretical aspect of socioeconomic security and its impact on the competitiveness of the regions.

Presentation of the main material and the substantiation of the results of the study. The regional development situation in Ukraine gives the greatest advantages to the sources of regional development and economic security. Currently, there is a concentration in the regions and metropolises that are characterized by innovation and investment potential, investment needs, production conditions (services) and specialization, ecology and a number of other specific features. The socio-economic security of the regions of Ukraine is best viewed as an environment that creates lasting ties in the system of national security of Ukraine. The growth of destabilizing factors 
leads to a deepening of differences in the levels of competitiveness of the regions of the state, which can turn into various kinds of dangers for the economy of the state.

The concept of «socioeconomic security» can be considered as a combination of economic and social conditions that ensure sustainable in the long run the production of the largest number of economic benefits per capita. Restricted resources should be considered as factors of the degree of independence from the conditions of foreign trade and the country's place in the world economic system. They often act as the resources of the country; create a greater number of economic benefits in order to ensure independence from imports and at the same time solve the problems of accumulation of society as much as possible knowledge, skills and abilities; the creation of goods that do not directly contribute to the welfare of citizens (power system, roads, armaments and armies), but the presence of which is a prerequisite for ensuring the welfare of society as a whole.

By its nature, the socio-economic security of the state is an integrated system that covers all sectors of the economy and all aspects of the life of the state and its population. The economic security of the state should take into account the economic interests of each of its citizens and groups of people, and combine them with national interests. At the same time, the priority is given to the level of security, which at the time is the most important [1].

The presence of regional aspects and their manifestations is one of the major problems of ensuring socioeconomic security in Ukraine. The main directions of its provision are manifested in the following factors [2]:

1. Improving the legal framework. Ensuring the adoption of unambiguous decisions in case of conflict situations between the center and the regions.

2. Preservation of resource potential, restoration, and development of production potential of the region.

3. Development of an independent fiscal and financial policy of the regions.

4. Training of skilled personnel of administrative management.

Socio-economic security of the regions as a system of actions is conditionally divided into the following components: energy security, financial, investment, innovation and social [3].
In the process of forming the concept of socio-economic security in the region, it is necessary to distinguish four main stages [2]:

1) a retrospective analysis of the socio-economic security of the region, which should be implemented, guided not only by the interests of the region but also the state as a whole;

2) determining the directions for ensuring the socio-economic security of the region;

3 ) forecasting the level of socioeconomic security of the region;

4) coordination of interests of ensuring the socio-economic security of the region with national interests.

The main objective of ensuring regional socioeconomic security is a comprehensive solution to the problem of transition to sustainable functioning and development of the region's economy, which provides stable economic growth by increasing the region's competitiveness, effective meeting public needs, high quality management, the ability to realize national interests in the region, ensuring decent living conditions of the population, elimination of emerging threats and protection of economic interests of business entities society [4].

The formation of a reliable system of socioeconomic security is one of the priority tasks of the interaction of national and regional interests in counteracting external and internal destructive influences and increasing the competitiveness of the regional economy.

V. Bezugla considers the competitiveness of the region as the ability of each regional system to manage its competitive advantages, rational and efficient allocation of productive forces in order to ensure a stable financial and economic situation, obtain maximum benefits, meet objective and subjective needs for conditions of self-sufficiency and self-financing within the limits of the current legislation [5].

E. Bruna and A. Skopin consider the competitiveness of the region as «the ability of the regional economy to ensure the welfare of the population of the region in an open economy» [6, p. 23]. In their opinion, a «normal» regional economy can provide the welfare of the population of the region, only by using quality factors of production, creating fundamentally new areas of the information economy and diversifying it. Only, in this case, it is possible to create additional jobs, a growth of the gross regional product and exports.

ISSN 1681-6277. Economics and law. № 2 (50), 2018 
Cambridge University economists B. Gardiner, R. Martin and P. Tyler emphasize the importance of the institutional and market structures of the region as factors of increasing its competitiveness and focus on labor productivity as a key indicator of the level of competitiveness of the region. Therefore, they argue that «regional competitiveness is the ability of a regional economic system to optimize local resources in order to successfully compete in national and international markets and to respond adequately and promptly to changes taking place in these markets [7].

The competitiveness of the region is a systemic and multi-faceted category that reflects a set of comparative advantages in different spheres (economic, technological, innovation-investment, personnel, commodity, market, etc.), the combination of which forms a more stable position in the market in a certain market or in certain spheres in the relevant time period in comparison with the determined competitors. The competitiveness of the region is shaped by the effective use of production, marketing, financial, scientific and technical, innovation - investment, personnel, property potential, and also due to flexible adaptation to changes in the functioning environment, and often - due to the advance of these changes.

The competitiveness of the region depends to a large extent on the competitiveness of the industries, the functioning of the Ukrainian economy as a whole, and the formation of a competitive environment. The latter, in turn, determines the conditions, the interaction and the nature of the rivalry between the subjects of regional activity.

The main features of the category «Region Competitiveness» [8]:

- comparability: the competitiveness of the region is determined and investigated in comparison with real competitors;

- spatiality: the competitiveness of the region is determined within a specific market, the sphere of activity, since on equal terms the region can be identified as competitive in one market and uncompetitive - on the other;

- dynamism: the concept of competitiveness is limited in time, because the region can be competitive in one period, and lose those positions in another period; that is, the competitiveness of the region is not a constant value;

- objectivity: provides for the selection of the list and a set of parameters that shape the competitiveness of the region;
- attributability: the distinction of a unique characteristic, which primarily forms the competitive advantage of the region;

- integrity: an assessment of the competitiveness of the region cannot be carried out according to one criterion, but necessarily based on the use of an integral indicator that accumulates the most representative indicators;

- taking into account internal and external conditions of operation: in assessing or forecasting the competitiveness of the region, it is necessary to take into account all the factors that have influenced or may have a potential impact on its formation;

- relevance: means that the competitive position of the region can only be determined within the relevant operating environment.

The definition of the concept of competitiveness of the region is considered from two approaches: the region as an environment that determines the competitiveness of enterprises operating in the region; and the region as an independent subject of competition.

The first approach considers the competitiveness of the region solely as a territory with its own characteristics, which in turn affects the competitiveness of enterprises. M. Porter for the analysis of the competitive environment of the region proposed Diamond model. According to this model, M.Porter finds the relation between the competitive advantages of the country and the competitive advantages of individual clusters - informal communities of industry and related companies characterized by the ability to mutually reinforce competitive advantages. Formation in a certain territory of the cluster contributes to increasing the competitiveness of other organizations of the territorial complex - the region. This model includes four key factors: factor conditions (e.g. infrastructure, knowledge, workforce, etc.), demand conditions (local consumer demand, production and consumer rules), competitive strategy (tax structure, competition law, individual company strategies), the presence of interactions interconnected and complementary industries. This set integrates into the concept of «industrial cluster», which provides a synergistic effect of interaction and forms the firm's competitiveness [9].

Features of the second approach are that the competitiveness of the region is considered as an independent participant in competitive relations, where the region acts as a holistic socio-ecological and economic system. Thus, the region, the local- 
ity, the city - not only the territory of the company's location, it is the living environment of people and as such is a non-renewable resource. There is a problem of contradiction between the interests of the «investor region» and their balancing, which can only be achieved within the framework of a well-developed regional policy [9]. Under these conditions, the regional policy becomes not only a region as a productive

The regional level combines local and national level. It embodies the system of relations for the provision of reproductive processes within a specific territory, the unity of the natural, material and social spheres. The region is an open socioeconomic system, the main function of which is the maximum production of material goods and services to meet the growing needs, including outside its territory.

Socioeconomic security can characterize the state of the region for a certain period of time, i.e. it is a static concept, while the competitiveness of its state directly at a specific time, that is, is a dynamic concept [10].

The interrelation between such spheres of the region as the society, the economy and the environment forms its special competitive advantages, which directly affect its competitive position.

Sustainable development of the region involves a comprehensive solution to the economic, social, environmental problems that are both global and national. However, these developmental problems need to be tackled first and foremost at the regional level, which requires the establishment of effective regional development programs.

The policy of regional development aimed at creating the same level of development of the regions of the state is not effective, as the poorly developed regions will be limited to obtaining subsidies and subsidies, while from a highly developed region, funds will be withdrawn that could be used to ensure their competitiveness.

The low level of competitiveness of the region can negatively affect socioeconomic security if the level of development of the region passes the maximum permissible safety indicators. In addition to this, the achievement of a high level of competitiveness of the region is not always accompanied by the provision of its economic security, which is connected, on the one hand, with the negative economic consequences of scientifically unwarranted economic reforms, the presence of unfair competition, and, on the other, the lack of inte- gration of the regions of the state into the national and rather high integration into the international economic space [11].

Therefore, the competitiveness of the regions of the state as an economic category is closely linked with the category «socio-economic security». The existence of competition for resources and benefits between the regions of the state should ensure their integration into a single economic, political, social, information space of the state and thus guarantee the construction of a developed, integrated country. This requires an effective system of governance, both country and region, to prevent the impact of negative factors and adapt quickly to changes in the environment, so that these negative phenomena do not escalate into a crisis.

The achievement of sustainable development security requires the development of a set of measures aimed at achieving the sustainability of the regional system, which involves a mechanism for counteracting negative factors. If regions, competing with each other, achieve sustainable development then it determines fair competition. Ensuring fair competition is possible by creating in the state for its regions identical conditions for the competitive struggle. If in a competitive environment the stability of the regional system is violated, it goes beyond the permissible limits and development becomes dangerous, then it requires regulatory actions of interregional competition. The development and implementation of mechanisms for state regulation of interregional competition and enhancement of the competitiveness of the region will allow achieving the desired result - ensuring fair competition and enhancing the competitiveness of the region [11].

Consequently, the same conditions of competition are the main administrative factor that stimulates the development of regions, that is, promoting fair competition at the regional level. In this case, the realization and mutual influence of the competitive advantages of the region is best ensured, with high socioeconomic security in the region.

Conclusions of the research. According to the results theoretical studies, the essence the concepts was clarified «socio-economic security» can be considered as a combination of economic and social conditions, this concept is an integrated system covering all branches of the economy and all aspects of the life of the state and its population. It has been established that socio-economic security directly affects the competitiveness of the re- 
gion. There are two approaches to the definition of the concept of competitiveness of the region, the first concept considers the region in terms of the environment, which determines the competitiveness of enterprises operating in this region, and the second region as an independent subject of competition. Socioeconomic security can characterize the state of the region for a certain period of time, that is, a static concept, while the competitiveness of its state at a particular moment of time, that is, is a dynamic concept. Both the low level of competition in the region and the high negative impact on the development of the region due to insufficient provision of socioeconomic security.

\section{СПИСОК ЛІТЕРАТУРИ}

1. Дічек О.І. Економічна безпека регіонів - складова системи національної безпеки. Вчені записки університету «КРОК». Серія : Економіка. 2013. Вип. 33. С. 24-30.

2. Резніков О.Л. Забезпечення соціально-економічної безпеки регіону - нагальне завдання сьогодення. Економіка промисловості. 2008. № 1. С. 78-82.

3. Методичні рекомендації щодо оцінки рівня економічної безпеки України. Національний інститут проблем міжнародної безпеки. За ред. А.І. Сухорукова. Київ, 2003. 64 с.

4. Кожухівська Р.Б. Менеджмент економічної безпеки та конкурентоспроможності підприємств туристичної індустрії у регіонах України. Сталий розвиток економіки. 2016. № 4 (21). С. 102-107.

5. Безугла В.О. Основи формування конкурентоспроможності регіонів України (на прикладі Полтавського регіону): автореф. дис. ... канд. екон. наук. 08.10.01. Харків, 2006. 20 с.

6. Брюна Э., Скопин А.Ю. Сравнительний анализ конкурентоспособности российских и французских регионов. Национальный исследовательский университет «Высшая школа экономики». 2004. URL: https://www.hse.ru/ data/632/480/1238/Bruna.pdf (дата обращения: 05.05.2018).

7. Назаров M.I. Конкурентоспроможність регіону: суть та властивості. Ефективна економіка. 2013. № 10. URL: http://www.economy.nayka.com.ua/?op=1\&z=2438 (дата звернення: 05.05.2018).

8. Романко О.П. Поняття конкурентоспроможності регіону та його ознаки. Ефективна економіка. 2015. № 3. URL: http://www.economy.nayka.com.ua/?op=1\&z=3869 (дата звернення: 05.05.2018).

9. Солоїд О.В. Концепція підтримки конкурентоспроможності малих підприємств. Вісник Хмельницького національного університету. 2011. № 6. С. 106-109.

10. Дегтярьова I.О. Механізми управління конкурентоспроможністю регіону: сутність та місце у системі механізмів управління державою. Державне будівництво. 2011. URL: www.kbuapa.kharkov.ua/e-book/db/2011-1/doc/4/06.pdf (дата звернення: 07.05.2018).

11. Герасимчук 3. Теоретичні засади забезпечення конкурентоспроможності регіону. Економіст. 2011. № 11. С. $34-37$.

Надійшла 07.06.2018

\section{REFERENCES}

1. Dichek O.I. Ekonomichna bezpeka rehioniv — skladova systemy natsionalnoi bezpeky. Vcheni zapysky universytetu «KROK». Seriia: Ekonomika. 2013. Iss. 33. S. 24-30 [in Ukrainian].

2. Reznikov O.L. Zabezpechennia sotsialno-ekonomichnoi bezpeky rehionu - nahalne zavdannia sohodennia. Ekonomika promyslovosti. 2008. No. 1. S. 78-82 [in Ukrainian].

3. Metodychni rekomendatsii shchodo otsinky rivnia ekonomichnoi bezpeky Ukrainy. Natsionalnyi instytut problem mizhnarodnoi bezpeky. Za red. A.I. Sukhorukova. Kyiv, 2003. 64 s. [in Ukrainian].

4. Kozhukhivska R.B. Menedzhment ekonomichnoi bezpeky ta konkurentospromozhnosti pidpryiemstv turystychnoi industrii u rehionakh Ukrainy. Stalyi rozvytok ekonomiky. 2016. No. 4 (21). S. 102-107 [in Ukrainian].

5. Bezuhla V.O. Osnovy formuvannia konkurentospromozhnosti rehioniv Ukrainy (na prykladi Poltavskoho rehionu): avtoref. dys. ... kand. ekon. nauk: 08.10.01. Harkiv, 2006. 20 s. [in Ukrainian].

6. Brjuna Je., Skopin A.Ju. Sravnitel'nij analiz konkurentosposobnosti rossijskih i francuzskih regionov. Nacional'nyi issledovatel'skij universitet «Vysshaja shkola jekonomiki». 2004. URL: https://www.hse.ru/data/632/480/1238/Bruna.pdf [in Russian].

7. Nazarov M.I. Konkurentospromozhnist rehionu: sut ta vlastyvosti. Efektyvna ekonomika. 2013. No. 10. URL: http://www. economy.nayka.com.ua/?op=1\&z=2438 [in Ukrainian].

8. Romanko O.P. Poniattia konkurentospromozhnosti rehionu ta yoho oznaky. Efektyvna ekonomika. 2015. No. 3. URL: http://www.economy.nayka.com.ua/?op=1\&z=3869 [in Ukrainian].

9. Soloid O.V. Kontseptsiia pidtrymky konkurentospromozhnosti malykh pidpryiemstv. Visnyk Khmelnytskoho natsionalnoho universytetu. 2011. No. 6. S. 106-109 [in Ukrainian].

10. Dehtiarova I.O. Mekhanizmy upravlinnia konkurentospromozhnistiu rehionu: sutnist ta mistse u systemi mekhanizmiv upravlinnia derzhavoiu. Derzhavne budivnytstvo. 2011. URL: www.kbuapa.kharkov.ua/e-book/db/2011-1/doc/4/06.pdf [in Ukrainian].

11. Herasymchuk Z. Teoretychni zasady zabezpechennia konkurentospromozhnosti rehionu. Ekonomist. 2011. No. 11. S. 34-37 [in Ukrainian]. 
О.Ю. Кудрина, Е.К. Даценко

Сумской государственный педагогический университет имени А.С. Макаренко, г. Сумы, Украина

СОЦИАЛЬНО-ЭКОНОМИЧЕСКАЯ БЕЗОПАСНОСТЬ КАК ФАКТОР ПОВЫШЕНИЯ УРОВНЯ КОНКУРЕНТОСПОСОБНОСТИ РЕГИОНА

Проанализировано понятие социально-экономическая безопасность в контексте государственного развития регионов. Рассмотрены вопросы влияния социально-экономической безопасности на конкурентоспособность региона, а также влияния конкуренции на развитие регионов. Изучены основные факторы и цели социально-экономической безопасности региона и основные свойства понятия конкурентоспособность региона.

Ключевые слова: устойчивое развитие региона, конкурентоспособность региона, экономическая безопасность региона, социально-экономическая безопасность региона.

О.Ю. Кудріна

orcid.org/0000-0002-7364-1998

Сумський державний педагогічний університет імені А.С. Макаренка, м. Суми, Україна

О.К. Даценко

orcid.org/0000-0002-0369-2132

Сумський державний педагогічний університет імені А.С. Макаренка, м. Суми, Україна

СОЦІАЛЬНО-ЕКОНОМІЧНА БЕЗПЕКА ЯК ФАКТОР

ПІДВИЩЕННЯ РІВНЯ КОНКУРЕНТОСПРОМОЖНОСТІ РЕГІОНУ

Дестабілізаційні фактори та нерівномірність розвитку регіону за низького рівня життя населення створюють середовище для зародження напруження в суспільстві. Це породжує загрози, що впливають на територіальну цілісність країни, стримує ринкові перетворення та знижує ефективність упровадження нових реформ у державі. Тому регіональна політика держави повинна бути спрямована на створення умов підвищення конкурентоспроможності регіонів як основи їх динамічного розвитку та усунення значних міжрегіональних диспропорцій. Соціально-економічну безпеку регіонів України найкраще розглядати як середовище, що породжує стійкі зв'язки у системі національної безпеки України. Зростання дії дестабілізаційних факторів призводить до поглиблення відмінностей у рівнях конкурентоспроможності регіонів держави, здатних перетворитись на різного роду небезпеки для економіки держави. Основна мета забезпечення регіональної соціально-економічної безпеки - комплексне вирішення проблеми переходу до сталого функціонування і розвитку економіки регіонів, за якого може бути забезпечено стабільне економічне зростання на основі підвищення конкурентоспроможності регіону, ефективне задоволення суспільних потреб, висока якість управління, здатність реалізації національних інтересів у регіоні, забезпечення гідних умов життєдіяльності населення, запобігання загрозам і захист економічних інтересів суб'єктів господарювання і суспільства в цілому. Соціально-економічна безпека характеризує стан регіону за певний період часу, тобто є статичним поняттям, тоді як конкурентоспроможність безпосередньо відображає його стан у конкретний момент, тобто є динамічним поняттям. Конкурентоспроможність регіону значною мірою залежить від конкурентоспроможності галузей економіки, які функціонують в України, та формування конкурентного середовища. Останнє у свою чергу визначає умови, взаємодію та характер суперництва між суб’єктами регіональної діяльності.

Ключові слова: сталий розвиток регіону, конкурентоспроможність регіону, економічна безпека регіону; соціальноекономічна безпека регіону. 